\title{
Cikkismertetés: Az elhízás rendszerszintű megközelítése
}

\author{
Article review: A systems approach to obesity
}

Ismertető: $\quad$ Erdei Gergő $\square$

Országos Gyógyszerészeti és Élelmezés-egészségügyi Intézet

Ismertetett cikk: Lee BY, Bartsch SM, Mui Y et al. A systems approach to obesity. Nutr Rev. 2017;75:94-106. doi: 10.1093/nutrit/nuw049

Beküldve: $\quad$ 2019. 02. 08.

doi: $\quad$ 10.24365/ef.v60i2.424

Kulcsszavak: globális egészség; modellezés; elhízás; rendszerek tudománya

Keywords: global health; modeling; obesity; systems science

\section{ÖSSZEFOGLALÁS}

Az elhízás globális járvánnyá vált, amely a társadalom minden rétegét érinti nemtől, kortól, iskolai végzettségtől és jövedelmi kategóriától függetlenül. A jelenleg érvényben lévő beavatkozások eddig nem változtatták meg az elhízás növekvő tendenciáját, ami arra utal, hogy innovatív megközelítésekre van szükség. Számos jel arra utal, hogy az elhízásjárvány rendszerszintű probléma, vagyis nem írható le egyetlen ok-okozati összefüggéssel. Az elhízás sikeres kezeléséhez emiatt rendszerszintû megközelítésre van szükség. Ennek számos előnye van, ideértve az elhízás kialakulásában szerepet játszó közvetett hatások részletesebb megértésének lehetőségét, vagy a politikai beavatkozások hatásainak ellenőrzését azok populációs szintre történő kiterjesztése előtt. Az alábbiakban 5 erőfeszítést mutatunk be, melyek az elhízás rendszerszintű megelőzésében kulcsfontosságúak: 1) több globális megközelítés alkalmazása; 2) olyan tudományterületek szakembereinek bevonása, akik hagyományos értelemben nem az elhízással foglalkoznak, hogy megosszák tapasztalataikat az elhízás területén dolgozó szakemberekkel; 3) rendszervizsgálati módszerek használata (pl. a rendszerek feltérképezése és modellezése); 4) a hagyományos megközelítések módosítása és összehangolása a rendszerek vizsgálatához; 5) a kutatás, az oktatás, a politika és a cselekvés között meglévő különbségek áthidalása.

\section{BEVEZETÉS}

Az elhízás globális járvánnyá vált, amely a társadalom minden rétegét érinti nemtől, kortól, iskolai végzettségtől és jövedelmi kategóriától függetlenül. Világszerte több mint 1,9 milliárd ember elhízott: 2004-ben az 5-10 éves gyermekek körülbelül 10\%-a, míg 2008-ban 40 millió óvodás korú gyermek volt túlsúlyos. Sok országban, szinte minden kontinensen emelkedik az elhízás aránya. A Föld népességének $65 \%$-a olyan országban él, ahol a túlsúly és az elhízás több halálesetet okoz, mint az alultápláltság. Az Amerikai Egyesült Államokban a felnőtt lakosság 70\%-a és a gyermekek 32\%-a túlsúlyos vagy elhízott, amely trend folyamatosan emelkedik. A jelenleg érvényben lévő beavatkozások eddig nem változtatták meg ezen tendenciákat, ami arra utal, hogy a probléma innovatív megközelítésére van szükség az elhízás megelőzése érdekében. Az Orvostudományi Intézet (Institute of 
Medicine) 2013-as jelentése alapján rendszerszintű megközelítésre van szükség az elhízás megfékezése érdekében.

A szerzők tanulmányukban ismertetik a rendszer fogalmát és megállapítják, hogy az elhízás rendszerszintű probléma. Ezt követően bemutatják, mit értenek rendszerszintű megközelítésen, illetve részletezik ennek előnyeit, valamint megvitatják azt az 5 kulcsfontosságú tényezőt, amely az elhízás rendszerszintű megközelítését foglalja magában.

\section{A RENDSZER?}

A rendszer különböző összetevőkből áll, amelyek egymáshoz kapcsolódnak, kölcsönhatásba lépnek és befolyásolják egymást. A természetes és emberalkotta rendszerek között említhetjük a meteorológiai, biológiai, szállítási, gyártási, pénzügyi, egészségügyi és élelmiszerrendszereket. Egy élelmiszerrendszerben az egyén közvetlen környezetében elérhető élelmiszerek típusa attól függ, hogy a kiskereskedők mit árulnak a kisebb és nagyobb üzletekben. A kisebb és nagyobb üzletek kínálata egyaránt a nagykereskedelmi beszállítók kínálatától függ, ami változhat a különböző típusú élelmiszerek iránti kereslet függvényében. A különböző típusú élelmiszerek iránti keresletet az élelmiszerek ára befolyásolja, amit a reklámozás és a társadalmi erők határoznak meg - érintve az élelmiszertermelóket és -feldolgozókat -, amelyek hatással vannak a gazdasági folyamatokra. Ezek az összetevők és a köztük lévő kapcsolatok sokféle és összetett módon lépnek kölcsönhatásba, túlmutatva egyetlen ok-okozati kapcsolaton.

A rendszer jellegzetessége, hogy egyik része sem teljesen független a többitől. A rendszer tulajdonságai ugyanis egymással összekapcsolódva, különböző módon befolyásolják egymást. A teljes rendszer magyarázata előtt meg kell érteni annak minden összetevőjét és azok kölcsönhatásait, hiszen az egyik rész jelentős módosításának hatására a rendszer többi részén utóhatások keletkeznek. Ezért a rendszer tökéletes megértése nélkül kihivást jelenthet a megfigyelt jelenség okának azonosítása, vagy egy beavatkozás hatásainak megjóslása. A probléma gyökerének nehéz azonosíthatóságára jó példa lehet, az alacsony jövedelmú városi területeken a tápanyagban gazdag élelmiszerek hiánya. Például, ha a közeli földeken nincs almatermelés, akkor az növeli az alma tárolásának költségét a kisebb forgalmú üzletekben. Ennek eredményeként előfordulhat, hogy csak a nagyobb szupermarketek engedhetik meg maguknak az almaárusítást, a gyümölcstárolás jelentős költsége miatt. Ha egy kisforgalmú élelmiszerüzlet az almaraktározás megoldására eszközöket vásárol, befektet, akkor a megnövekedett költség valószínúleg a vásárlóra hárul. Ha az alma magas ára miatt nem kel el hiszen a megnövekedett költséget a kereskedő a beépíti az árba -, az élelmiszerhulladék keletkezéséhez vezethet, és elrettentheti a bolt tulajdonosát az almatárolástól. Hacsak nem tudjuk, hogyan múködik ez az élelmiszerrendszer, nehéz lehet a megfigyelt jelenség okát megtalálni. Ebben a példában az almahiány oka vajon a kereskedők üzleti gyakorlata, avagy a gazdák növénytermesztési gyakorlatának változásában keresendő? Egy ehhez hasonló probléma helyes diagnosztizálása és kezelése megköveteli az élelmiszerrendszer összetevőinek ismeretét, megértését és az ezek közötti kapcsolatok feltérképezését.

Annak ellenére, hogy a rendszer összetevői egymással kapcsolatban állnak, a rendszerszemléletű megközelítés megköveteli, hogy a kutató körülhatárolja a rendszert. A rendszer határai elválasztják azt más rendszerektôl, meghatározva, hogy mely összetevőket tartalmazzák és melyeket zárják ki. A rendszer határai lehetnek földrajzi, vagy fogalmi elemek, de vonatkozhatnak folyamatokra is. Mivel sok rendszer erősen összekapcsolódik egymással, a határok nem mindig egyértelműek. A rendszer határaira vonatkozó döntéseket a vizsgált kutatási kérdés vagy probléma vezérli. A „takarékosság elvét" követve a határokat akár olyan módon rajzolhatnánk meg, hogy a kutatási kérdéshez kapcsolódó összetevők és folyamatok túlnyomó többségét (>80\%-át) tartalmazza, néhány összetevőt szükségszerűen kizárva. Például, ha a tanulók üdítőitalfogyasztást kívánjuk korlátozni, akkor nemcsak az iskolai üdítőital-automaták számát kell csökkenteni, hanem az iskola közelében lévő élelmiszerboltok kínálatát is figyelembe kell venni, mert a gyermekek az automaták kínálatának korlátozása 
miatt más forrásból is beszerezhetik az üdítőitalokat; a határ megrajzolása esetében azonban ki kell zárni a nem az iskola közelében található üzleteket, mert nem valószínű, hogy a gyermekek túlságosan nagy távot tennének meg az üdítőital beszerzése miatt.

\section{MIÉRT RENDSZERSZINTŰ PROBLÉMA AZ ELHÍZÁS?}

Számos jel arra utal, hogy az elhízásjárvány rendszerszintû probléma, nem egyszerû ok-okozati összefüggés következménye, emiatt rendszerszintú megközelítést igényel. A következő okok magyarázzák, hogy az elhízás rendszerszintű probléma: globális hatókör, heterogén mintázat, széleskörű hatások, az egykomponensű beavatkozások kudarca.

\section{Globális hatókör}

Az elhízás globális járvánnyá vált, amely számos országot és társadalmi csoportot érint. Sok alacsony jövedelmű országban, ahol korábban az alultápláltsággal küzdöttek, most az elhízással néznek szembe. Az elhízás által érintett országok sokfélesége azt sugallja, hogy egy olyan egyszerű, egyedi tényező, mint a nagymennyiségú élelmiszer könnyű elérhetősége, nem ad kellő magyarázatot a járvány jelenlétére, ezért holisztikus megközelítésre van szükség ahhoz, hogy megértsük a probléma mögötti rendszert.

\section{Heterogén mintázat}

A járvány által érintett országokban az elhízás elterjedése eltérő mintákat mutat, amelyek nehezen magyarázhatók. Az elhízás előfordulási aránya az 1980-as években sokkal nagyobb mértékben kezdett emelkedni, mint az előző évtizedekben, 1980 óta aránya több mint kétszeresére nőtt. Emellett fontos megjegyezni, hogy egy adott országban az elhízás alakulása gyakran jelentősen különbözik a különböző társadalmi csoportok között. Például az Amerikai Egyesült Államokban bizonyos belvárosi területeken, egyes társadalmi-gazdasági csoportok között nagyobb mértékú növekedés történt. Ezek a komplex minták nem magyarázhatók egyszerű ok-okozati viszonnyal.

\section{Széleskörű hatások}

Az elhízás széleskörű és összetett következményekkel jár. Az elhízás egyik jellemzője, ami az összetettség egy oka is, az időeltolódás. A testtömegben mutatkozó változások hosszú időn keresztül alakulhatnak ki; emellett a testtömeg-változás és következményeinek megnyilvánulása között késés is fennállhat. A következmények nem magyarázhatók közvetlen hatásokkal, mint például a magas vérnyomás, az érelmeszesedés, a 2-es típusú cukorbetegség vagy a daganatos megbetegedések, illetve magukban foglalják a kirekesztést, a depressziót és az alacsony önbecsülést. Más szóval az elhízás hatásai széles körűek, és olyan biológiai, pszichológiai, társadalmi hatásokat eredményeznek, amelyek befolyásolják az élet jellemzőit, mint a fizikai egészség, alvási minták, produktivitás, társadalmi kapcsolatok és önértékelés. Ezen komplex következmények sokasága jelentős betegség- és költségterhet eredményez nemcsak az egyén, hanem a társadalom számára is.

\section{Komplex okok}

Nemcsak az elhízás következményei, hanem annak okai is komplexnek tekinthetők. Az eddigi kutatási eredmények nem azonosítottak egyetlen okot, amely az elhízásjárványért felelős lenne. A bizonyítékok arra utalnak, hogy az elhízás kialakulásához több tényező járulhat hozzá, melyek különböző szinteken jelentkeznek. Az 1. ábra az elhízáshoz kapcsolódó különböző szinteket mutatja be, beleértve a genetikát, az élettani tényezőket, az egyéni viselkedést, a társadalmi kapcsolatokat, a fizikai, épített környezetet és a társadalompolitikai erőket. A biológiai szint olyan élettani folyamatokat tartalmaz, mint a leptin-érzékenység és az egyedi anyagcsere. Az egyéni viselkedés magába foglalja az étrendi és fizikai aktivitási döntéseket, míg a társadalmi hálózatokat a családi és baráti kapcsolatok alkotják, amelyek befolyásolhatják az egyén viselkedését is. A környezeti szint magában foglalja az élelmiszerek elérhetőségét, a testmozgáshoz szükséges zöldterületeket és a közlekedés biztonságát. 
A társadalompolitikai erők közé tartozik a gazdaság, a politika, az oktatás, az egészségtudatosság és a kultúra. Ezeknek a szinteknek mindegyike különböző tényezőkkel rendelkezik, amelyek közvetlenül vagy közvetve elhízáshoz vezethetnek. Például az élelmiszer-forgalmazási gyakorlatok változása és a fizikai aktivitás csökkentése 2 olyan tényező, amit gyakran az elhízás növekvő arányának okaként tartanak számon. Mindazonáltal mindkét tényező különböző egységekből áll. A marketing befolyásolja az épített környezetet és az egyes élelmiszerek elérhetőségét. Az épített környezet jellemzői, például a parkok és rekreációs központok elhelyez- kedése, befolyásolják az egyének fizikai aktivitásra való hajlamát. Mind a marketinget, mind az épített környezetet a társadalmi erők, például a gazdaság hajtják. A marketingüzenetek sokszor társas kapcsolatainkon keresztül jutnak el hozzánk, ezzel is befolyásolva az étrendi vagy fizikai aktivitási szokásokra gyakorolt hatásukat. A marketingüzenetek hatásukban is különböznek az egyén pszichológiai tényezői, például a hiedelmek és az elfogultságok alapján. Az egyéni biológia és a genetika meghatározza az energiafelvétel és -leadás dinamikáját. Sőt, egy személy környezete befolyásolja a genetikai kifejeződését (epigenetika) is.

1. ábra: Az elhízás kialakulásában szerepet játszó tényezők

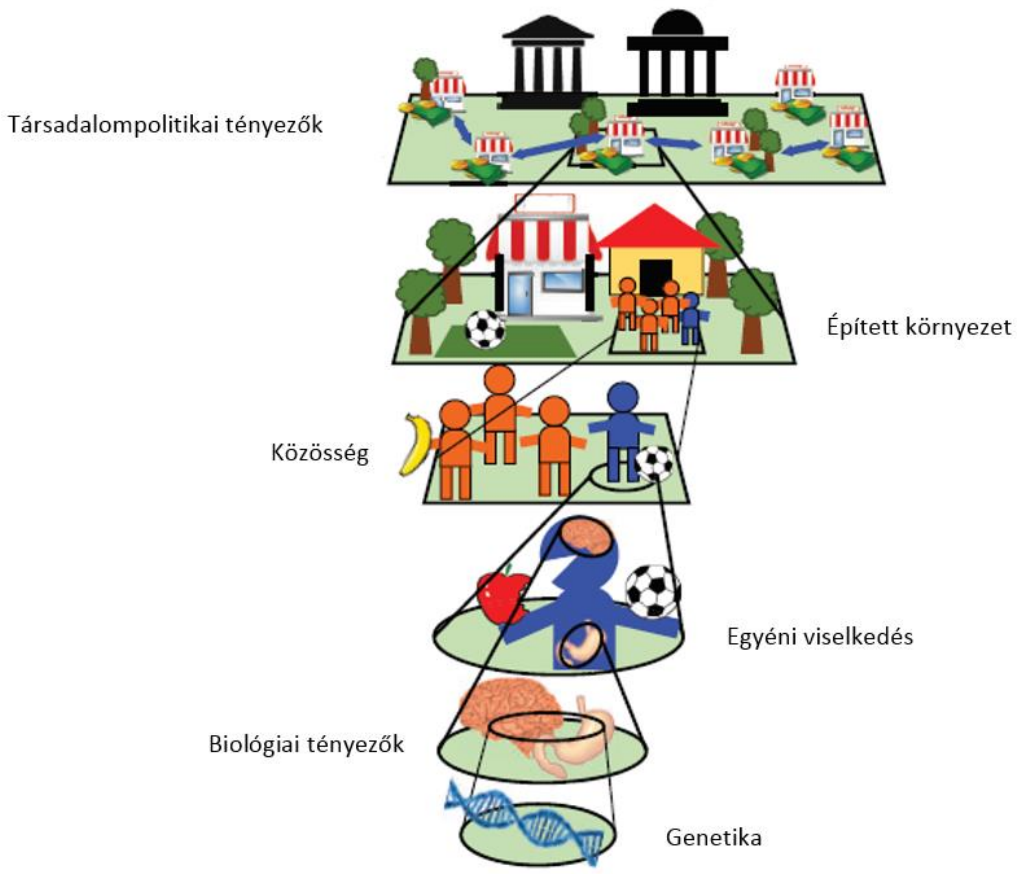

Forrás: Saját szerkesztés Lee, Bartsch, Mui et al., 2017 alapján

Ez csak néhány azon tényezők közül, amelyek részt vehetnek az elhízás kialakulásában. Természetesen ezek közül némelyik lehet közvetett hatású, és nem feltétlenül tekinthető az elhízás közvetlen okának, de az, hogy ezen tényezők együttesen alkotnak egy rendszert, elvitathatatlan. Míg az adott szinteken belül néhány kisebb folyamatot részletesen ismerünk, addig hiányzik egy olyan tudományos keret, amely ezeket az ismereteket hasznositható módon összekapcsolná. Például mélyreható ismeretekkel rendelkezünk az egyes epigenetikai és pszichológiai jelenségekről, valamint arról, hogy a politikai döntések és a környezet hogyan kapcsolódnak a viselkedéshez és az egészségi hatásokhoz, de ezeket az eredményeket együttesen nem tudjuk értelmezni. Ezt az eredményezi, hogy fontos okok és közvetítők ismerete hiányzik a rendszerből. 
Meg kell jegyezni, hogy a kapcsolat 2 tényező között nem mindig egyértelmű. Például Salvy és mtsai vizsgálták a gyerekek és serdülők étrendjére és testmozgásra gyakorolt társas hatásokat. A fizikai aktivitásra vonatkozó vizsgálatok azt sugallják, hogy a társak jelenléte növelheti a gyerekek fizikai aktivitását (a motiváció és a fizikai aktivitás jutalmazó értéke és normatív jellege révén), ugyanakkor csökkenthetik is a fizikai aktivitást (kiközösítéssel, elnyomással és kirekesztéssel). A táplálkozásra vonatkozó vizsgálatok arra a következtetésre jutottak, hogy a társak jelenléte növelheti is a serdülök energiafelhasználását (a társas viselkedés utánzása révén), ugyanakkor csökkentheti is az energiafelvételt (közösségi környezetben az egészséges táplálkozási normák elősegítése révén).

Egy meglévő keret, amely leírja az elhízás komplex okait, a "6C modell”. Az emberi fejlődés Bronfenbrenner-féle ökológiai modelljére építve Harrison és mtsai áttekintették a szakirodalmat, és kidolgozták a gyermekkori elhízás „6C modelljét”, ami összefoglalja a gyerekkori elhízás kialakulásában szerepet játszó legnagyobb jelentőségú tényezőket. A modellben szerepel a sejt (Cell; genetikai hajlam és egyéb biológiai tényezők), a gyermek (Child; a gyermek jellemzői), a család (Clan; családi jellemzők), a közösség (Community; társak, iskolai és egyéb csoportok jellemzői), ország (Country; állami és nemzeti politikák, programok és prioritások) és kultúra (Culture; normák, mítoszok és elfogultságok, amelyek a viselkedést irányítják). A „6C" közül egyik sem tekinthető az elhízás kizárólagos okának, ugyanakkor a "6C" elemei mind, összetett módon kölcsönhatásba lépnek egymással.

\section{Nincs egyetlen megoldás}

Azt a gondolatot, hogy az elhízás rendszerszintű probléma, tovább erősíti, hogy eddig még egyetlen olyan megoldást sem találtak sikeresnek, amely mindössze egy kiváltó ok kezelésére koncentrál. Annak ellenére, hogy sok különböző étrend, edzésprogram és beavatkozás van érvényben, amelyek az elhízás kialakulásában szerepet játszó egy tényezőre hatnak, az elhízás gyakoriságának mértéke tovább emelkedett világszerte. Ugyanakkor a többszintű, többkomponensű beavatkozások sikeresek voltak. Ennek az az oka, hogy a többkomponensú beavatkozások célzott és testre szabott elemeket tartalmaztak (például egészségnevelés, étrend megváltoztatása, fizikai aktivitás népszerúsítése, képernyő előtt töltött idő csökkentése, egyéni viselkedést és motivációt befolyásoló hatások), amelyek így nagyobb hatást gyakoroltak az elhízás visszaszorítására, mint az egyes összetevők elkülönítve.

\section{A rendszerszintű politikák és beavatkozások előnyei}

A rendszerszintű megközelítés figyelembe veszi a teljes rendszert a megfigyelési, döntési és változtatási folyamatok során. Az olyan területek, mint a légiforgalmi irányítás, a szállítás, a gyártás és a pénzügy, különböző módszereket alkalmaztak a rendszerek jobb megértésére már a döntések meghozatala előtt. Ez a rész leírja a rendszerek fontosságát a döntési folyamatok és a beavatkozások használata során. Amint a 2. ábra mutatja, a rendszerszintű megközelítés megkönnyítheti a valódi megoldások azonosítását, felmérheti a megoldások hosszú távú fenntarthatóságát, megértheti a közvetett hatásokat és a nem szándékolt következményeket, informál az adatgyűjtés priorizálásáról, és tesztelheti a beavatkozásokat a populációs szintre történő kiterjesztés előtt.

Ha problémák merülnek fel, a rendszerszintű megközelítés megkönnyítheti a megoldások keresését, a probléma okának direkt kezelésével ahelyett, hogy átmeneti megoldást kínálna. Ha a döntéshozók nem ismerik a probléma fő okát, vagy annak széleskörű hatásait, akkor a megoldásul választott technika nem oldja meg teljesen a problémát. Ez a típusú hozzáállás elfedi a problémát ahelyett, hogy valódi megoldást nyújtana. Így fennáll annak a kockázata, hogy az ilyen típusú megoldások csak súlyosbíthatják az egészségegyenlőtlenségeket. Például, ha az egyéneket egészséges élelmiszerek fogyasztására ösztönözzük, akkor csak azoknál érhetünk el változást, akik rendelkeznek elegendő idővel és erőforrással ezeknek az élelmiszerek a megvásárlásához és elkészítéséhez. Azonban sokan nem férnek hozzá egészséges ételekhez, mivel a környezetükben lévő üzletek nem árulnak elég gyümölcsöt és zöldséget. Mások a napi stressz és a munka mellett nem tudnak elegendő időt

\footnotetext{
Bronfenbrenner U. The Ecology of Human Development: Experiments by Nature and Design. Cambridge, MA: Harvard University Press; 2009.
} 
fordítani arra, hogy vásároljanak és főzzenek. Még akkor sem, ha egészséges ételeket árusító üzletek közelében élnek, vagy az is előfordulhat, hogy nincs elég pénzük az egészségesebb élelmiszerfélék megvásárlásához. Ezért az oktatási kampányok segíthetnek ugyan, de alapvetően nem javítják az élelmiszerkörnyezetet. Egy másik példa az iskolai üdítőital-automaták eltávolítása, ami csökkentheti az iskolán belüli üdítőital-vásárlást, de növelheti is annak arányát az iskolán kívüli üzletekben.

A rendszer-megközelítés lehetővé teszi a döntéshozók számára, hogy értékeljék a megoldások hosszú távú fenntarthatóságát. Ha a probléma alapjául szolgáló okot nem kezelik, a "megoldás” átmenetileg múködhet, de idővel és a körülmények megváltozásával elveszthetik a hatékonyságukat. Például, az áruházak számára az egészséges élelmiszerek elérését ösztönző tényezők rövid ideig tartó jelenléte időlegesen megváltoztathatja az üzletek termékkínálatát, ám ha az üzletek nem rendelkeznek megfelelő infrastruktúrával (mint például a romlandó élelmiszerek megfelelő hútésével), akkor hamarosan olyan élelmiszerek kerülnek raktározására, amelyek hosszabb ideig tárolhatók, és nagyobb irántuk a kereslet, mint például a nagy energiasűrűséggel rendelkező nassolni valók.

2. ábra: A rendszer-megközelítés elönyei a politika és a beavatkozások számára

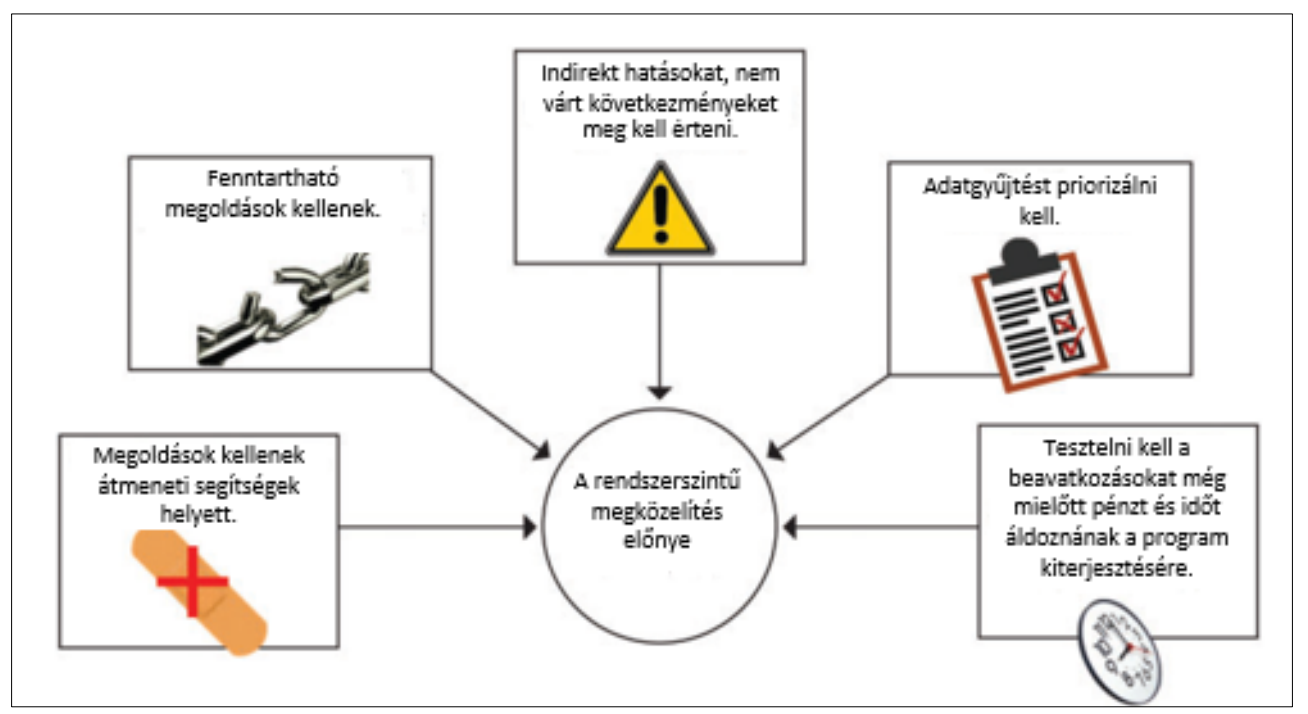

Forrás: Saját szerkesztés Lee, Bartsch, Mui et al., 2017 alapján

A közvetett hatások és a nem szándékolt következmények rendszerszintú megközelítéssel könnyebben azonosíthatók. Egy döntéshozó alábecsülheti a problémát, mert nem tudja felmérni időben a teljes hatást. Például a döntéshozók nem fogják felismerni a nem megfelelő élelmiszerkörnyezet teljes hatását, mivel a túlsúly és az elhízás gyakorisága hosszú időn keresztül növekszik, és az ilyen trendek megfordítása jelentős időt és energiát igényel. Ha egy személy nem ismeri a különböző döntések teljes hatását, még a jó értelemben vett erőfeszítések sem járhatnak a kívánt következményekkel. Ha előírjuk a bolttulajdonosoknak, hogy bővítsék az egészséges élelmiszerek kínálatát és ehhez nem biztosítjuk számukra, hogy fenntarthassák vagy növelhessék nyereségüket, az arra motiválhatja őket, hogy csökkentsék a kínálatot, ezáltal még kedvezőtlenebbé válik az élelmiszerkörnyezet.

A rendszerszintű megközelítés információt adhat az adatgyüjtés priorizálásról annak érdekében, hogy elkerüljék a felesleges vagy akár félrevezető információk gyűjtését. Az adatgyűjtéshez idő, energia és erőforrások szükségesek, ezért nehézkes döntéseket hozni az összegyújtendő adatokról. Továbbá a rendszeresen végzett, átfogó adatgyűjtés megfizethetetlenül drága és megvalósíthatatlan. Ezen túlmenően bizonyos politikai tényezők vagy gazdasági érdekek befolyásolhatják a döntéshozókat a prioritások kezelésében. Ezzel szemben egy több tudományág képviselőit egyesítő csapat bevonása 
csökkentheti az egyéni torzítások hatásait, valamint a döntéseket és az eredményeket egyértelmúbbé és átláthatóbbá teszik. A rendszer megértése így segíthet az adatgyűjtés irányításában és a prioritások meghatározásában. Például az étkezési és fizikai aktivitás folyamatos értékelése meglehetősen drága lehet. Korlátozott erőforrások mellett mik lehetnek a legmagasabb értékű adatok, amelyeket érdemes gyűjteni? Milyen információk segítenék leginkább a döntéshozatalt és az érdemi változtatásokat? Milyen adatok adnák a legpontosabb képet a rendszerről?

Végül a rendszerszintű megközelítés lehetővé teszi, hogy a döntéshozók gyakorlatilag teszteljenek egy beavatkozást, mielőtt azt a valós környezetben végrehajtanák, ezáltal időt, energiát és erőforrásokat takaríthatnak meg. Ha a rendszer nehezen érthető, a hatékony beavatkozások tervezése és kivitelezése hosszabb időt vehet igénybe. A tervezési folyamat eredményei és tanulságai nagyban segíthetik a program hatékony múködését.

Például, egyes elhízásmegelőzési beavatkozások javasolják, hogy az iskolákból távolítsák el az üdítőital-automatákat. Taber és mtsai viszont megállapították, hogy azon iskolák tanulói, ahol nincs üdítőital-automata, hetente több üdítőitalt fogyasztanak, és gyakrabban esznek gyorséttermi ételt. Ezek az eredmények azt sugallják, hogy az automata csak egyike a komplex rendszer számos összetevőjének. Az iskolai automaták esetében a rendszerek modellezése lehetővé tette a kutatók számára, hogy azonosítsák a nem kívánt következményeket és ennek megfelelően alakítsák ki a beavatkozást a végrehajtás előtt.

\section{Az elhízás rendszerszintű megközelítése}

Míg sok iparág régóta használja a rendszerszintű megközelítést, az elhízás megelőzése és nyomon követése terén az ezen jellegú beavatkozások eddig elmaradtak. Hasonló késés tapasztalható az egészségügy és a népegészségügy más területein is, de a rendszerszintû megközelítés bizonyos lépéseket már megtett a fertőző betegségek megelőzése és nyomon követése terén, ezzel segítve a döntéshozókat a fertőző betegségek terjedésének megértésében, a fertőző betegségek következményeivel és a különböző ellenőrző intézkedések lehetséges hatásaival kapcsolatban.
Mi az oka annak, hogy az elhízás rendszerszintű megközelítése eddig elmaradt? Ennek egyik oka lehet, hogy az elhízást a közelmúltig egyéni és nem népegészségügyi problémának tekintették. $\mathrm{Az}$ a kijelentés, hogy az elhízás most már globális járvány, megváltoztathatja ezt a nézőpontot. A rendelkezésre álló bizonyítékok alátámasztják az egyénen kívüli egyéb tényezők fontosságát. A másik ok az lehet, hogy a kutatók nem ismerik a rendszerek vizsgálati módszereit, amely hiányosság részben az oktatásból fakad. Bár a matematikai modellezés számos üzleti és mérnöki képzettséghez szükséges, a rendszerszintű megközelítések elmélete hagyományosan nem része a táplálkozás- és orvostudomány, valamint a népegészségügy és az egészségügyi politika képzéseknek. A táplálkozástudomány, az orvostudomány és a népegészségügy problémái nagyon jól kezelhetők lennének rendszerszintű megközelítéssel. Számos általános kihívás létezik különböző területeken, mint például a bizonytalanság, az adatok hiánya, több érdekelt fél együttes jelenléte és az erőforrások korlátai. Területenként eltérő ezen kihívások jellege és mértéke. Sok területen magas a tét (pl. költségek, betegségek, halálozás) és az elhízásjárvánnyal kapcsolatos kérdések összetettségére való tekintettel még inkább fontos a rendszerszintű megközelítés. Az alábbiakban bemutatásra kerülő erőfeszítések segítségével a rendszerszintű megközelítés módszerei megkönynyíthetik a jelenlegi döntéshozatali módszereket, nem pedig kiszorítják azokat.

Tekintettel arra, hogy az elhízás megelőzése és nyomon követése elmaradottnak tekinthető, a rendszerszintű megközelítések alkalmazásának elfogadásában az alábbi 5 erőfeszítés segíthet:

\section{Erőfeszítés: a globális megközelítés alkalmazása}

A rendszerszintű megközelítés fontos része annak a megértése, hogy az elhízás globális probléma. A világ országai egyre inkább összekapcsolódnak az utazás, a kommunikáció, a gyártási gyakorlatok, az élelmiszerrendszerek és a különböző társadalmi viselkedési normák által. Ez a kapcsolati rendszer azt jelenti, hogy az egyik országban bekövetkezett változások más országokban is megjelennek, mégpedig az egyes országok kontextusában eltérő módon. Ezért az elhízásjárványra vonatkozó megközelítéseknek egyre inkább figyelembe kell venniük ezeket 
a globális kapcsolati rendszereket, és a különböző országoknak együtt kell múködniük. A többi globális egészségügyi kezdeményezéshez viszonyítva - mint például a himlő felszámolása vagy az egész világra kiterjedő influenzajárvány megfékezése -, ezen a területen eddig viszonylag kevés példa volt nemzetközi koordinációra, és az országhatárokon átnyúló kezdeményezések száma, a ráfordítások nagysága korlátozott volt. A formális elhízásmegelőzési és nyomonkövetési tevékenységek többsége eddig helyi szinten történt. Ez alól kivételt képez a cukorral édesített italokra kivetett népegészségügyi termékadó, mely Mexikóból indult, és ma már több országban, így hazánkban is alkalmazzák.

\section{Erőfeszítés: különböző tudományterületek ismereteinek hasznosítása}

Történelmünk nagyszerű kihívásai több tudományterület tudósainak együttmúködését igényelték. Erre példa az Amerikai Egyesült Államok úrsikló programja, melyben a repüléstechnikai szakemberek munkáját segítették táplálkozási szakértők - az űrhajósok étel- és folyadékigényének megértetésével -, pszichológusok - a stressz fontosságának ismertetésével -, valamint számos más szakember. Ezen szakértők bevonásának elmulasztása megakadályozhatta volna a misszió sikerességét. Az előbbi példához hasonlóan az elhízás megelőzéséhez is számos olyan tudományág együttmúködésére lenne szükség, amelyek hagyományos értelemben véve nem foglalkoznak az elhízással, mint például a mérnöki és informatikai tudományok. Ezek fontos új perspektívákat és módszertani megközelítéseket hozhatnak. Szükségünk lesz olyan szakértők útmutatására is, akik mély ismeretekkel rendelkeznek az elhízás területén leginkább a táplálkozás, az epidemiológia és a pszichológia tudományágaiban, mivel a kapcsolódó területek kérdései közül sok jóval bonyolultabb, mint azt korábban gondoltuk.

\section{Erőfeszítés: rendszertudomány módszertaná- nak használata}

A rendszer megértésének két fő eszköze annak feltérképezése és modellezése. Ebben a részben ezen módszereket ismertetjük, bemutatjuk alkalmazási területeiket és új irányokat tárgyalunk. A rendszerszintű megközelítés kritikus első lépése az egész rendszer általános képének meghatározása.
A rendszerek feltérképezése azt mutatja, hogy miként illeszkednek és lépnek egymással kölcsönhatásba a rendszer különböző részei. Először konszenzust kell kialakítani a rendszer határairól és összetevőiről. Ehhez az érdekelt felekből álló csoportban javaslatokat dolgoznak ki és vitatnak meg arról, hogy mely összetevőket kell bevonni és kizárni. Egy rendszer összetevőinek azonosítása önmagában számos tényre rávilágíthat. Első pillantásra előfordulhat, hogy nem vesszük észre, bizonyos emberek, csoportok, szervezetek vagy egyéb tényezők szerepet játszanak a rendszerben. Az összetevők azonosítása után a csoport meghatározza, hogy ezek az összetevők hogyan kapcsolód-hatnak egymáshoz. A csoport különböző platformokat használhat ezeknek az összetevők és kapcsolataik megjelenítéséhez, például poszteren, táblán vagy a számítógép képernyőjén megjelenő hatás-, hálózati vagy okozati hurokdiagramok rajzolásával. Számos szoftvercsomag áll már rendelkezésre ilyen diagramok elkészítésére ( $p l$. STELLA, Vensim és Powersim).

Különösen hasznos lehet a több tudományág képviselőit egyesítő csoportok bevonása a rendszerek feltérképezési folyamatába, mivel egy személy nem rendelkezik a rendszer minden részének megértéséhez szükséges szakértelemmel. Például egy élelmiszerrendszer feltérképezésekor a várostervező leírhatja, hogy a különböző élelmiszerforrások, például élelmiszerboltok elhelyezkedése hogyan befolyásolhatja az élelmiszerekhez való hozzáférését. Egy közgazdász számszerüsítheti az árképzés és a különböző élelmiszerek iránti kereslet közötti kapcsolatot. Egy múveleti kutató felvázolhatja az élelmiszer-ellátási láncot és a gyártók, a szállítók, valamint a kiskereskedők közötti kapcsolatokat. Egy mezőgazdasági szakember megvilágíthatja a termelés meghatározóit. A szociológus rávilágíthat, hogy a különböző társadalmi hatások, mint például a társak, megváltoztathatják az élelmiszervásárlási magatartást, ami viszont hatással van az élelmiszerkiskereskedőkre. A táplálkozási szakértők meghatározhatják, hogy az egyes élelmiszerek fogyasztása hogyan befolyásolhatja a lakosság egészségét.

A második módszer a rendszermodellezés, amelyben a matematikai egyenleteken alapuló számítógépes programokat a rendszer összetevőinek, kapcsolatainak és folyamatainak ábrázolására használják.

A fentiekben leírt rendszerek feltérképezése 
gyakran megelőzi a modellezési folyamatot. Az érdeklődésre számot tartó kutatási kérdés alapján a modellezők meghatározhatják a rendszert és annak határait. Emellett a modellezők a rendelkezésre álló adatokból, meglévő irodalmi adatokból, megalapozott elméletekből és helyszíni szakértőktől származó információk alapján határozhatják meg a modell bemeneti adatait. Míg egy rendszer modellje a valóság egyszerúsített ábrázolása, a rendszermodell fejlesztésének fontos jellemzője az, hogy minden lépésben ellenőrzik a modellt. A fejlesztés minden szakaszában a modell kulcsfontosságú szereplőknek való bemutatása javíthatja a modell jóságát (vagyis az érdekelt felek egyetértenek abban, hogy a modell képviseli azt, amit szükséges képviselnie). A modell futtatása és az eredmények összehasonlítása a valós eredményekkel és hasonló tanulmányokkal javíthatja a modell érvényességét (vagyis az adatok azt mutatják, hogy a modell összhangban van a valós eredményekkel). Az ellenőrzött modellek ezután lényegében „virtuális laboratóriumként" szolgálhatnak annak vizsgálatára, hogy a rendszer hogyan múködik, és teszteli a rendszeren belüli különböző változások hatásait. A számítógépes modellezés egyik bevált példája a légiforgalmi irányítórendszerek. A légiforgalmi irányítórendszerek a különböző forrásokból (például az időjárási adatokról, a környezetről, a kifutópálya-kapacitásról és a helyről) származó információkat kombinálják azzal, hogy miként hatnak egymásra ezek a tényezők (például az időjárási minták hogyan befolyásolják a repülési időt és útvonalakat). Ezután egy számítógépes modellt használnak a rendszer összes összetevőjének és folyamatának ábrázolására annak érdekében, hogy segítsék a felhasználókat a rendszer egészének megértésében és megfelelő döntések meghozatalában. Annak ellenére, hogy ezek nem múködnek tökéletesen - például az utazók számára késés tapasztalható - a légiforgalmi irányítási rendszerek nélkül a modern légi közlekedés nem lenne lehetséges. Ezek a rendszermodellek teszik lehetővé számunkra a napi múveletek összehangolását, a rendszer sebezhetőségeinek diagnosztizálását, valamint az új technológiák hatásainak előrejelzését.

Annak ellenére, hogy vannak kezdeti modellek, az élelmiszer-, táplálkozási és elhízási problémák kezelésére szolgáló rendszerek módszereinek használata továbbra is kezdetlegesnek mondható. Egy specifikus módszer, amely a társadalmi hálózatokat elemzi, annak érdekében, hogy megtudjuk, az emberek hogyan kapcsolódnak egymáshoz és megvizsgálja, hogy ezek a kapcsolatok hogyan befolyásolhatják az étrendet, a fizikai aktivitást és az elhízást. A társadalmi hálózat elemzése csomópontokat használ az egyének, csoportok vagy szervezetek képviseletére. A csomópontok között húzott vonalak (más néven élek vagy kötések) a társas kapcsolatokat képviselik. Ez nemcsak arra szolgál, hogy vizuálisan bemutassa, miként kapcsolódnak az egyének, hanem segítségével a kapcsolatok mintáit is jellemezzük, és elemezzük: ezek hogyan korrelálhatnak a viselkedésekkel és az egészségügyi eredményekkel. Az ilyen elemzések kimutatták, hogy a társadalmilag összefüggő egyének általában hasonló étkezési szokásokkal és hasonló fizikai aktivitási mintázatokkal rendelkeznek. Így lehetett megmagyarázni, hogy a Framingham tanulmánybanii az elhízott egyénekkel társas kapcsolatokat létesítő személyek nagyobb valószínűséggel váltak elhízottá.

A rendszermodellek alkalmazásával a tervezett beavatkozások tesztelésére tervezett programokról és szakpolitikákról előzetes információkhoz juthatunk. A tervezett beavatkozások előzetes vizsgálata segíthet azonosítani, hogy mely beavatkozások vagy azok kombinációi - a leghatékonyabbak egy adott környezetben. Az úgynevezett egység alapú modellezés (agent-based-model, azaz ABM) használatával összehasonlítva a szupermarketekhez való hozzáférést, a fizikai aktivitás infrastruktúráját és az iskolai minőséget, Orr és mtsai megállapították, hogy mindhárom beavatkozás csökkentette a testtömegindexiii közötti különbségeket az afro-amerikai és a fehér társadalmi csoportok között, de észrevették, hogy néhány beavatkozás idővel felerősítette egymás hatását. A beavatkozá-

\footnotetext{
ii A Framingham városában végzett epidemiológiai vizsgálat a szív- és keringési rendszer kockázati tényezőinek szerepét kutatta és bizonyította. www.framinghamheartstudy.org

iii A testtömegindex egy mérőszám, ami megmutatja, hogy az egyén alultáplált, normál súlyú, túlsúlyos vagy elhízott. Számítási módja: testtömegindex $=\frac{\text { testtömeg }(\mathrm{kg})}{\text { testmagasság }{ }^{2}\left(\mathrm{~m}^{2}\right)}$ http://apps.who.int/bmi/
} 
sok között egy ilyen kölcsönhatás volt jelen az Auchincloss és mtsai által kidolgozott ABM-ben is, amely kimutatta, hogy a megfizethető egészséges élelmiszerekhez való hozzáférés és az egészség élelmiszerek preferenciái a különböző jövedelmű háztartások közötti táplálkozási különbségek csökkentése érdekében szükségesek. A rendszerek modellezése azonosithat olyan körülményeket, amelyek egy adott beavatkozást többé-kevésbé sikeresé tehetnek. Li és mtsai megállapították, hogy a táplálkozással kapcsolatos oktatási kampány hatása az egyének élelmiszerválasztási lehetőségeire a társadalmi normáktól függően változó volt.

A tanulmány elméleti betekintés voltára magyarázat, hogy a jelenlegi szakirodalom csak a rendszermodellek használati lehetőségeinek felületét karcolja. A következő lehetséges lépések közé tartozik a különböző befolyásoló tényezők és folyamatok eddig nem ismert elemeinek feltérképezése, az egyre össze-tettebb rendszermodellek kialakítása valós adatokkal és létező kapcsolatokkal, a modellek által lefedett releváns rendszerek típusainak és aspektusainak bővítésével, valamint a rendszerek modelljeinek bővítésével. Mint korábban említettük, a rendszertudományi módszerek, mint például a rendszerek feltérképezése és modellezése, képesek az elhízás megelőzésére és monitorozására. Előfordulhat azonban, hogy ezek a módszerek és eszközök az elhízás megközelítésére nem bizonyulnak megfelelőnek és az elhízás megelőzése, valamint az egyéb területek közötti különbségek miatt szükség lesz módosításra. Lehetséges, hogy új modelleket és módszereket kell kidolgozni, avagy szükség lehet a meglévő modellek és módszerek módosítására. Az elhízás megelőzését és monitorozását célzó rendszereknek gazdasági, operatív, epidemiológiai és klinikai szempontokat kell hatékonyan kombinálniuk. Ellentétben a gyártási rendszerekkel, ahol cél a teljesítmény maximalizálása a költségek minimálisra csökkentésével, a táplálkozás és az egészség szempontjából a meglévő rendszermodelleket relevánsabb struktúrákkal szükséges bővíteni. Például, hogy az élelmiszerellátás egyes meglévő modelljei olyan operatív intézkedésekre összpontosítsanak, mint az idő, az értékesítés és a nyereség, de ezeket az intézkedéseket táplálkozási és egészségügyi eredmények nem támasztják alá.
4. Erőfeszítés: rendszerszintű szemlélet használata hagyományos megközelítésben

A rendszerszintú megközelítés nem a hagyományos népegészségügyi módszerek helyettesítésére szolgál. Valójában a rendszertudomány módszerei segíthetnek a már meglévő módszerek javításában. [3. ábra] A modellezés segíti az időben vissza- és előretekintő vizsgálatok tervezését, a logisztikát, valamint a lehetséges eredmények előrejelzését. A modellezés az időben vissza- és előretekintő tanulmányok eredményeit más helyzetekre és körülményekre is kiterjesztheti. A modellezés ugyancsak segíthet a különböző, időben vissza- és előretekintő vizsgálatok eredményeinek egyesítését is. Emellett a modellezés segíthet a korábbi és a jövőbeli vizsgálatok eredményeinek a valós döntéshozatalra vonatkozó szakpolitikákra és beavatkozásokra történő lefordításában.

\section{Erőfeszítés: a kutatás, az oktatás, a szakpolitika és a beavatkozások összekapcsolása}

A rendszertudomány bevonása az elhízás megelőzésére és visszaszorítására változásokat hoz a kutatásban, az oktatásban, a politikában és a beavatkozásokban. Amint azt korábban említettük, a rendszerszintű megközelítések hagyományosan nem voltak részei az elhízással kapcsolatos tudományágak oktatási programjának. Emiatt a klinikusok és a döntéshozók nem tartják szem előtt a rendszerek fontosságát, esetleg nem látják a kutatási erőfeszítések és a döntéshozatal közötti kapcsolatot. Ezeknek a tevékenységeknek szinergiában kell lenniük ahelyett, hogy különállóként léteznének. Ha a kutatók megértik a klinikai és politikai megfontolásokat, akkor képesek lehetnek nagyobb hatású beavatkozások kidolgo-zására. Azon döntéshozók, akik a kutatások eredményeit helyesen értelmezik, azonosíthatják azokat az innovációkat, amelyek hasznosak az adott környezetben.

A kutatás, az oktatás és a politika összekapcsolása számos stratégiával érhető el. A rendszertudományi szakemberek átadhatják a rendszerszintű gondolkodás készségét az egészségügyi szakembereknek és döntéshozóknak. Például a képzés kiterjedhet a rendszerszintű megközelítés fontosságára, a 
rendszertudomány módszereire, valamint arra, hogy a rendszerszintű gondolkodás, megközelítés miként építhető be a megfelelő szakterületekbe. A rendszerkutatók más kutatókkal és döntéshozókkal együtt-múködve kidolgozhatnak olyan további rendszer-modelleket, amelyekkel jobban megérthetik az adott rendszerhez kapcsolódó kérdéseket vagy szakpolitikákat: a legfontosabb befolyásoló tényezők azonosítása, a rendszer múködésébe való beavatkozás lehetséges következményeinek feltárása és a nem kívánt következmények felismerése. A rendszertudományi megközelítés segíthet a döntéshozóknak azon stratégiák azonosításában, amelyek segítségével a szakpolitikai döntéseket a leghatékonyabbak lehetnek. Erre példa a leghatékonyabb élelmiszercímke elhelyezése az adott célközönség elérése érdekében.

\section{3. ábra: A modellezés müködése a gyakorlatban.}
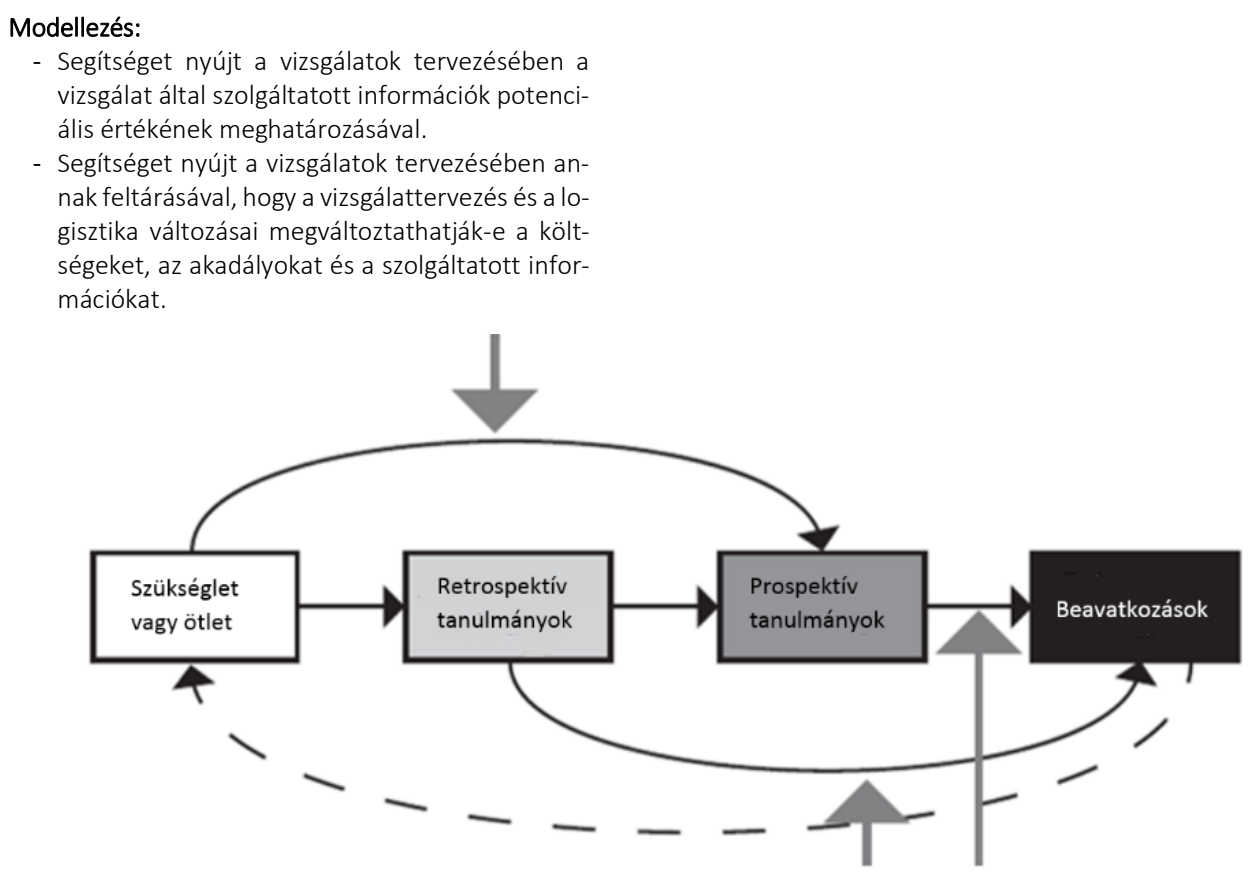

Modellezés:

- Szakpolitikák, termékek és beavatkozások tervezésének és fejlesztésének segitése, a potenciális hatások bemutatásával.

- Az adatgyűjtés priorizálása a különböző típusú információk hatásának bemutatásával.

\begin{abstract}
Modellezés:
- A kutatási eredményeket beavatkozások tervezésre és végrehajtásra fordítja.

- Integrálja különböző vizsgálatok eredményeit.

- Megmutatja, mi történhet, ha a körülmények megváltoznak.

- Virtuális laboratóriumként szolgál olyan vizsgálatok elvégzésére, amelyek egyébként túl költségesek vagy megvalósíthatatlanok lennének.
\end{abstract}

\section{TANULSÁGOK A HAZAI SZAKEMBEREK SZÁMÁRA}

Jelen közlemény alapján a rendszerszintű megközelítést érdemes lenne alkalmazni a hazai gyakorlatban is. Az ehhez szükséges képzésnek azonban előbb meg kellene jelennie az orvosok és az egészségügyi szakdolgozók kurrikulumában is. 